\title{
VALIDATION OF A NEW SOIL VOC SAMPLER
}

Topical Report

Reporting Period March 1996 - March 1997

By

Susan S. Sorini

John F. Schabron

April 1997

Work PerformedUnder Cooperative Agreement

DE-FC21-93MC30127 Task 21

For

En Chem Inc.

Green Bay, Wisconsin

and

U.S. Department of Energy

Office of Fossil Energy

Federal Energy Technology Center

Morgantown, West Virginia

By

Western Research Institute

Laramie, Wyoming 


\section{DISCLAIMER}

This report was prepared as an account of work sponsored by an agency of the United States Government. Neither the United States Government nor any agency thereof, nor any of their employees, make any warranty, express or implied, or assumes any legal liability or responsibility for the accuracy, completeness, or usefulness of any information, apparatus, product, or process disclosed, or represents that its use would not infringe privately owned rights. Reference herein to any specific commercial product, process, or service by trade name, trademark, manufacturer, or otherwise does not necessarily constitute or imply its endorsement, recommendation, or favoring by the United States Government or any agency thereof. The views and opinions of authors expressed herein do not necessarily state or reflect those of the United States Government or any agency thereof. 


\section{DISCLAIMER}

Portions of this document may be illegible in electronic image products. Images are produced from the best available original document. 


\section{ACKNOWLEDGMENTS}

The authors wish to acknowledge Chris Reitmeyer and the other staff members of En Chem, Inc. who are helping with this project. Funding for this study is being provided by the U.S. Department of Energy, Federal Energy Technology Center, under Cooperative Agreement Number DE-FC21-93MC30127 and by En Chem, Inc., Green Bay, Wisconsin.

\section{DISCLAIMER}

This report was prepared as an account of work sponsored by an agency of the United States Government. Neither the United States Government nor any agencies thereof, nor any of their employees, makes any warranty, expressed or implied, or assumes any legal liability or responsibility for the accuracy, completeness, or usefulness of any information, apparatus, product, or process disclosed, or represents that its use would not infringe on privately owned rights. Reference herein to any specific commercial product, process, or service by trade name, trademark, manufacturer, or otherwise does not necessarily constitute or imply its endorsement, recommendation, or favoring by the United States Government or any agency thereof. The views and opinions of authors expressed herein do not necessarily state or reflect those of the United States Government or any agency thereof. 


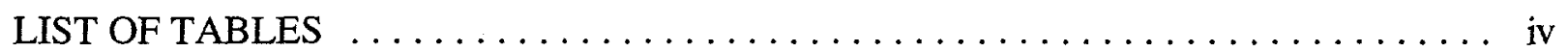

EXECUTIVE SUMMMARY $\ldots \ldots \ldots \ldots \ldots \ldots \ldots \ldots \ldots \ldots \ldots \ldots, \ldots \ldots$

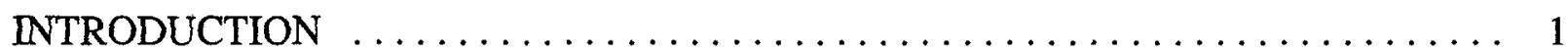

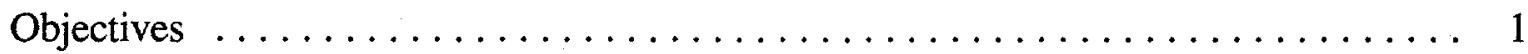

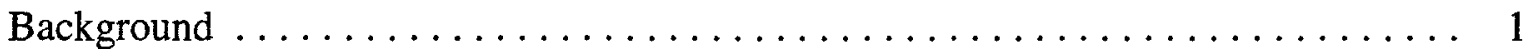

EnCore $^{\mathrm{TM}}$ Sampling/Storage Device $\ldots \ldots \ldots \ldots \ldots \ldots \ldots \ldots \ldots \ldots \ldots \ldots \ldots \ldots \ldots \ldots$

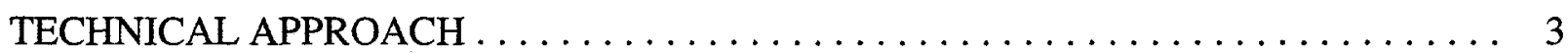

Initiation of ASTM Standard Development Activities $\ldots \ldots \ldots \ldots \ldots \ldots \ldots \ldots, 3$

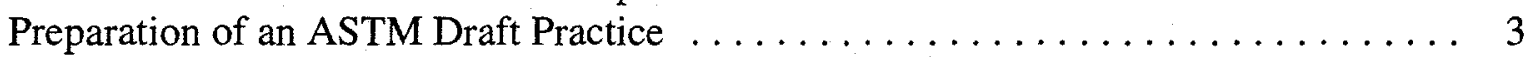

Testing Plan for Determining Maximum Storage Times and Temperatures ........ 4

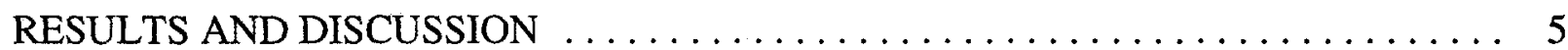

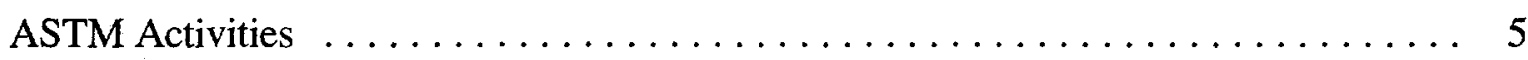

Determination of Maximum Storage Times and Temperatures $\ldots \ldots \ldots \ldots \ldots 6$

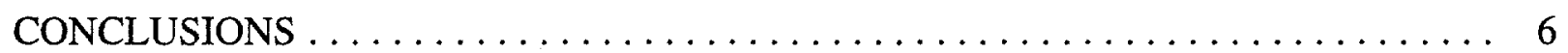

REFERENCES $\ldots \ldots \ldots \ldots \ldots \ldots \ldots \ldots \ldots \ldots \ldots \ldots \ldots \ldots \ldots \ldots \ldots \ldots \ldots \ldots \ldots \ldots$

APPENDIX A

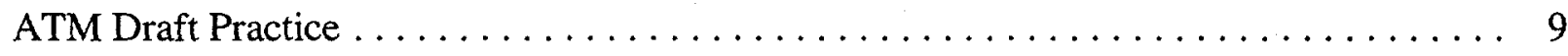

APPENDIX B

Test Planning for Determining Maximum Storage Times and Temperatures $\ldots \ldots \ldots \ldots 20$ 


\section{LIST OF TABLES}

Table

Page

1. Example of Time-Zero Data for the Sand/Clay Mixture $\ldots \ldots \ldots \ldots \ldots \ldots$ 


\section{EXECUTIVE SUMMARY}

Beginning in October 1996, Western Research Institute (WRI) initiated method development and validation work for a new soil sampling/storage device for volatile organic compounds (VOCs) that has been developed by En Chem, Inc., Green Bay, Wisconsin. The device is known as the EnCore ${ }^{\mathrm{TM}}$ sampler. En Chem is participating in this project as the corporate cosponsor. This report describes the initial phases of the work.

The overall objective of the project is to facilitate national acceptance of the EnCore ${ }^{\mathrm{TM}}$ sampling/storage device by conducting product tests, method development, and method validation activities. During the first six months of this project, interaction with American Society for Testing and Materials (ASTM) Committee D-34 on Waste Management was initiated to obtain ASTM support for development of a draft practice for using a device fitting the description of the EnCore ${ }^{\mathrm{TM}}$ sampler. A draft practice has been prepared for review within ASTM and subsequent approval as an ASTM standard for sampling and storing soil for volatile organic analysis. In addition, the testing required to establish maximum storage temperatures and times to prevent loss of VOCs due to volatilization and/or biodegradation for inclusion in the ASTM practice has been planned and is currently in progress. 


\section{INTRODUCTION}

\section{Objectives}

The overall objective of this project is to facilitate national acceptance of the EnCore ${ }^{\mathrm{TM}}$ sampling/storage device by conducting product tests, method development, and method validation activities. The specific goals for the initial six-month period of the project are listed below.

- Evaluate and become familiar with the stainless steel EnCore ${ }^{\mathrm{TM}}$ sampling/storage device for collecting and holding soil samples for determination of volatile organic compounds (VOCs).

- Initiate interaction with American Society for Testing and Materials (ASTM) Committee D-34 on Waste Management to begin the ASTM standard preparation and approval process.

- Prepare an ASTM draft practice for using a device fitting the description of the EnCore ${ }^{\mathrm{TM}}$ sampler for sampling and storing soil for volatile organic analysis. Under ASTM guidelines, the procedure describing the use of a device, such as the EnCore ${ }^{\mathrm{TM}}$ sampler, is referred to as a practice rather than a method because it is a definitive set of instructions for performing one or more specific operations that does not produce a test result (ASTM 1996a).

- Plan testing needed to establish maximum storage temperatures and times for inclusion in the ASTM practice.

\section{Background}

A major problem in sampling soil for volatile organic analysis is preservation of sample integrity during storage and shipment of soil samples to the laboratory for analysis. This issue was emphasized during a series of discussions and presentations at a national symposium dedicated to state-of-the-art techniques and research needs for soil VOC measurement (King 1993). Current methods for collecting and storing soil VOC samples have been shown to result in volatilization losses during collection and storage of samples over periods of 24-48 hours. In a series of studies undertaken by En Chem, Inc. and the Wisconsin Department of Natural Resources, four methods for collecting and storing soil samples were compared (Turriff and Kloop 1995). These were methanol preservation, brass tube, U.S. Environmental Protection Agency (EPA) bottle method, and use of the stainless steel EnCore ${ }^{\mathrm{TM}}$ sampler. Results of the studies show that laboratory data can grossly underestimate the actual VOC concentrations in a soil if careful attention is not paid to sample storage. For the EPA bottle method, time periods of as little as two hours resulted in losses of VOCs. Losses were not observed with methanol preservation or the EnCore ${ }^{\mathrm{TM}}$ sampler in a 48-hour period. 
These are also the only two of the four methods evaluated that do not involve subsampling. However, there are some problems associated with methanol preservation. Use of methanol in the field can pose problems associated with flammability hazards, shipping restrictions, and dilution of samples containing low VOC concentrations. As a result, the EnCore ${ }^{\mathrm{TM}}$ sampler appears to be the device of choice for sampling and storing soil for VOC analysis.

\section{EnCore ${ }^{\mathrm{TM}}$ Sampling/Storage Device}

The EnCore ${ }^{\mathrm{TM}}$ sampler provides a simple means for sampling soils and for holding the soil samples in a vapor-tight chamber during shipment to the laboratory for VOC analysis. If volatile contaminant levels in the soil are not known, the device can hold the sample so the proper sample preparation method, low-level or high-level, can be determined by screening a replicate sample. Once this determination is made, the sample for analysis is transferred without disturbing its integrity into the appropriate container for analysis or preservation in methanol.

Because the EnCore ${ }^{\mathrm{TM}}$ sampler appears to be a very suitable device for sampling and storing soil for VOC analysis, this project was initiated to facilitate national acceptance of the device. Initial stages of this activity involve further evaluating the performance of the sampling/storage device and preparing an ASTM practice that provides a procedure for using the device. In a study of soil VOC sampling and storage, two mechanisms of VOC loss during storage were noted (Turriff et al. 1995). These are losses due to volatilization and losses due to bacterial degradation. A soil sampling/storage protocol for VOCs must take both of these mechanisms into account, and storage times and temperatures to prevent loss of VOCs due to volatilization and/or biodegradation from the time of sample collection until analysis or transfer to methanol in the laboratory must be provided.

ASTM approval of a protocol for using a device fitting the description of the EnCore ${ }^{\mathrm{TM}}$ sampling/storage device is important to national acceptance. This is especially true with the recent passage of public law 104-113 (March 7, 1996) which states, "...all federal agencies and departments shall use technical standards that are developed by voluntary consensus standards bodies." In addition, the U.S. EPA is working closely with ASTM to accelerate approval of certain field sampling procedures. One of these activities involves revising and updating ASTM Standard D-4547, Standard Practice for Sampling Waste and Soils for Volatile Organics (ASTM 1996b). The new practice describing use of a sampling/storage device, such as the EnCore ${ }^{\mathrm{TM}}$ sampler, will be referenced in the revision of D-4547, which will give the EnCore ${ }^{\mathrm{TM}}$ device additional exposure. 


\section{TECHNICAL APPROACH}

\section{Initiation of ASTM Standard Development Activities}

This task began in October 1996. During the first six months, activities to stimulate national acceptance of the EnCore ${ }^{\mathrm{TM}}$ sampler for use as a soil sampling/storage device for VOCs were started. As part of this, the activity to develop an ASTM standard practice for using a coring tube for sampling and storing soil for volatile organic analysis was introduced to ASTM Task Group D34.01 .01 on Environmental Sampling. This practice will provide information for using a device fitting the description of the EnCore ${ }^{\mathrm{TM}}$ sampler for sampling and storing soil for volatile organic analysis. Items that were emphasized during discussion with the ASTM task group were (1) the sampling tube serves as a sealed sample storage chamber after a sample is collected in the tube, (2) the practice will not use methanol in the field, and (3) the practice will also include data and information on maximum storage times and temperatures, as well as information on the precision of the technique. Members of the task group were in support of these items and also expressed support of the practice because it will not require laboratory personnel to weigh out, stir, or excessively handle soil samples prior to volatile organic analysis. The members of the task group recommended that development of the practice proceed. Development of the draft practice was also discussed during a meeting of ASTM Subcommittee D-34.01 on Sampling and Monitoring. The members of the subcommittee also support this activity.

In addition, the U.S. EPA has selected revising and updating ASTM Standard D-4547, Standard Practice for Sampling Waste and Soils for Volatile Organics (ASTM 1996b), for support as one of their ASTM accelerated standard activities. Work on this revision has been started, and WRI personnel are also participating in this activity. The new ASTM practice for using a coring tube for sampling and storing soil for volatile organic analysis developed under the current project will be referenced in the revision of D-4547. In addition, D-4547 is referenced in the new draft practice.

\section{Preparation of an ASTM Draft Practice}

A draft practice for sampling and storing soil for volatile organic analysis has been prepared for review within ASTM and subsequent approval as an ASTM standard practice. A copy of the draft practice is provided as Appendix A of this report.

The practice describes a procedure for using a coring tube for sampling and storing soil for volatile organic analysis. It provides a simple means for holding soil samples for volatile organic analysis during shipment to the laboratory. If the volatile contaminant levels in the soil are not known, the sample can be held so that the proper sample preparation method, low-level or high-level, 
can be determined by screening a replicate sample. Once this determination is made, the sample for analysis is transferred without disturbing its integrity into the appropriate container for analysis or preservation in methanol. The practice does not use methanol preservation in the field.

The EnCore ${ }^{\mathrm{TM}}$ sampler fits the description of the sampling/storage device described in the apparatus section of the practice (Appendix A, Section 5.1). The specified device is described as any cylindrical tube that is volumetrically designed to collect a five-gram sample and is equipped with (1) a slide-on cap having a vapor-tight seal, such as provided by a Viton O-ring in the cap, and (2) a plunger for nondisruptive extrusion of the sample into an appropriate container for analysis.

Currently, the draft practice specifies sample storage at temperatures that do not exceed $4{ }^{\circ} \mathrm{C}$ for no longer than 48 hours before transfer of the sample for the appropriate high or low-level volatile analysis, or sample storage at temperatures that do not exceed $-15^{\circ} \mathrm{C}$ for no longer than a period of time that is currently being determined. Laboratory testing is being performed to verify that sample storage at temperatures that do not exceed $4^{\circ} \mathrm{C}$ for no longer than 48 hours is acceptable for preventing loss of volatile compounds due to volatilization and/or biodegradation and to determine the appropriate length of time for sample storage at temperatures that do not exceed $-15^{\circ} \mathrm{C}$ to prevent loss of volatile compounds due to volatilization and/or biodegradation. After these determinations are made, the maximum sample holding times and temperatures will be specified in the practice. Information on the laboratory testing performed to determine these values is provided in an appendix to the practice. This will give the user information on how the storage conditions specified in the practice were determined. The plan for testing to determine the maximum storage times and temperatures is described below. After the testing is completed and the maximum storage times and temperatures are determined, the draft practice will be balloted within ASTM Subcommittee D-34.01 on Sampling and Monitoring for review and comments. This is expected to occur later in 1997, depending on progress of the testing.

\section{Testing Plan for Determining Maximum Storage Times and Temperatures}

The plan for testing required to determine the maximum sample storage times at temperatures not exceeding $4^{\circ} \mathrm{C}$ and $-15^{\circ} \mathrm{C}$ to prevent loss of volatiles due to volatilization and/or biodegradation using the EnCore ${ }^{\mathrm{TM}}$ sampler is provided as Appendix B of this report. It calls for testing three soil types. These are a sand ( $~ 85 \%$ sand $/ \sim 15 \%$ clay), a loamy clay low in bacterial population, and a loamy clay high in bacterial population. Ten percent deionized water by weight is to be added to the soils to simulate natural hydration. The soils are to be spiked with gasoline plus a mixture of halogenated solvents (1,2-dichloroethane, trichloroethylene, and tetrachloroethylene). Spiking is to be performed so that sample preservation in methanol is required for analysis (high-level sample preparation method). The soils are to be homogenized with respect to both soil composition and 
contaminant levels by placing the soil, along with the contaminant spike, in a 20 -gallon drum having ten mixing blades welded to its interior surface. The drum is to be sealed and then placed inside an insulated, refrigerated box having a temperature ranging from 7 to $12^{\circ} \mathrm{C}$. Mixing is to be performed by horizontally rotating the drum at 5.5 rotations per minute for 16 to 18 hours.

After each soil is mixed for 16 to 18 hours, the plan calls for ten five-gram samples to be collected and immediately extruded into methanol for preservation and analysis. These samples are to be analyzed to give time-zero concentrations of the compounds of interest in the soil and to provide homogeneity information on the spiked soil.

After each soil is mixed for 16 to 18 hours, the plan also calls for additional samples to be collected using the EnCore ${ }^{\mathrm{TM}}$ sampling/storage device. These samples are to be stored at $4^{\circ} \mathrm{C}$ and $-15^{\circ} \mathrm{C}$ for various lengths of time prior to volatile organic analysis for the analytes of interest. The bias introduced by storage of the samples in the sampling/storage device will then be statistically evaluated as described in ASTM D-2777, Standard Practice for Determination of Precision and Bias of Applicable Methods of Committee D-19 on Water (ASTM 1991). The bias will be evaluated for significance at the $5 \%$ level. Temperatures and storage times that do not result in significant loss of the VOCs of interest at a 5\% significance level will be selected for specification in the ASTM practice. Before the practice is balloted, final verification testing, which is also described in Appendix $B$, will be performed as a final check of the practice.

The test plan calls for first testing stainless steel EnCore ${ }^{\mathrm{TM}}$ samplers and then repeating the tests using EnCore ${ }^{\mathrm{TM}}$ samplers constructed of a disposable inert polymeric material. The testing outlined in the plan has been started using the stainless steel devices and a soil type of $\sim 85 \%$ sand with $\sim 15 \%$ clay, which is designed to represent a worst-case scenario for volatilization.

\section{RESULTS AND DISCUSSION}

\section{ASTMActivities}

As discussed, ASTM standard development activities have been initiated. An ASTM draft practice (Appendix A), which applies to the use of the EnCore ${ }^{\mathrm{TM}}$ sampler, has been prepared and will be taken through the ASTM review process starting later in 1997. Work has also been performed in relation to the accelerated standards activity involving revision of ASTM Practice D-4547. Three drafts of this revision have been reviewed by WRI personnel, and comments and suggested changes have been provided. The revision of D-4547 is currently being balloted within ASTM Subcommittee D-34.01 on Sampling and Monitoring. 


\section{Determination of Maximum Storage Times and Temperatures}

As described above and in the plan provided as Appendix B to this report, testing using the soil type of $\sim 85 \%$ sand with $\sim 15 \%$ clay, which is designed to represent a worst case scenario for volatilization, has been started. However, at this time, a problem with some of the equipment not being within required specifications has been encountered. As a result, the first set of time-zero data that were generated for the sand/clay mixture will not be used in determining maximum sample storage times for the EnCore ${ }^{\mathrm{TM}}$ devices. This is because the testing in which these data were generated was stopped due to the storage device prototypes not sealing properly and VOCs being lost through volatilization. However, the time-zero data generated by this initial testing can be used to provide an example of the time-zero data that can be expected for the sand/clay mixture.

In the initial testing, the time-zero concentrations of the analytes of interest in the samples of the spiked sand/clay mixture were determined by immediate analysis of the samples using EPA Method 8021 (U.S. EPA 1990). The mean concentrations of the analytes of interest in the time-zero samples, as well as the standard deviations, percent relative standard deviations, and $95 \%$ confidence intervals for the replicate values determined for each compound, are listed in Table 1. As mentioned, these data provide an example of the time-zero data that can be expected for the sand/clay mixture.

Based on the data listed in Table 1, it can be assumed that the sand/clay mixture was well homogenized with respect to the concentrations of the analytes of interest. The percent relative standard deviation values are greater than $5 \%$ for only three compounds, benzene, 1,2dichloroethane, and trichloroethylene, and none of the percent relative standard deviation values for any of the compounds of interest are greater than $10 \%$. These data show that the method of preparing the contaminant-spiked sand/clay mixture is effective in homogenizing the material for testing.

Activities are currently being performed to correct the equipment specification problem for the sampling/storage devices. Once this problem is corrected, testing using the sand/clay mixture in the stainless steel EnCore ${ }^{\mathrm{TM}}$ sampling/storage devices will be performed as described in the test plan (Appendix B).

\section{CONCLUSIONS}

In the early stages of this project, good progress has been made toward initiating ASTM standard development activities; preparing an ASTM draft practice applicable to the EnCore ${ }^{\mathrm{TM}}$ sampling/storage device; and planning testing for determining maximum storage times and temperatures for inclusion in the ASTM practice. In addition, preliminary data show that the method of preparing the contaminant-spiked sand/clay mixture for determining maximum sample storage times and temperatures is effective in homogenizing the material for testing. 
Table 1. Example of Time-Zero Data for the Sand/Clay Mixture ${ }^{\text {a }}$

Test Material/

Compound
Mean Standard \% Relative

Concentration

$(\bar{x})$

Deviation Standard

(s)

Deviation

$95 \%$

$\simeq \mathbf{8 5} \%$ Sand $/ \sim 15 \%$ Clay

Benzene

Toluene

Ethylbenzene

M/P-Xylene

O-Xylene

1,3,5-Trimethylbenzene

1,2,4-Trimethylbenzene

1,2-Dichloroethane

Trichloroethylene

Tetrachloroethylene
2,451

17,356

5,843

23,078

8,989

5,100

15,692

812

1,921

784
223

657

132

401

169

118

350

82

142

34
$9 \%$

$4 \%$

$2 \%$

$2 \%$

$2 \%$

$2 \%$

$2 \%$

$10 \%$

$7 \%$

$4 \%$
$2,279-2,623$

$16,850-17,861$

$5,742-5,945$

$22,770-23,387$

$8,859-9,120$

$5,009-5,191$

$15,423-15,962$

749-875

$1,812-2,030$

$758-810$

${ }^{\mathrm{a} U n i t s}$ are $\mathrm{mg} / \mathrm{ks}(\mathrm{ppb})$ unless otherwise stated. 


\section{REFERENCES}

American Society for Testing and Materials, 1991, ASTM Practice D-2777-86, Standard Practice for Determination of Precision and Bias of Applicable Methods of Committee D-19 on Water. Annual Book of ASTM Standards, 11.01: 31-44.

American Society for Testing and Materials, 1996a, Form and Style for ASTM Standards, 10th Ed., West Conshohoken, Pennsylvania.

American Society for Testing and Materials, 1996b, D-4547, Standard Practice for Sampling Waste and Soils for Volatile Organics. Annual Book of ASTM Standards, Vol. 11.04: 40-43.

King, P., 1993, Evaluation of Sample Holding Times and Preservation Methods for Gasoline in FineGrained Soils. Proceedings from the National Symposium on Measuring and Interpreting VOCs in Soils: State-of-the-Art and Research Needs, U.S. EPA, Las Vegas, NV.

Turriff, D.E., and C. Klopp, 1995, Comparison of Soil Preservation and Analysis Methods for VOC Analytes. Proceedings of the Field Screening Methods for Hazardous Wastes and Toxic Chemicals International Symposium, Air \& Waste Management Association, pp. 1236-1237.

Turriff, D.E., C. Reitmeyer, L. Jacobs, and N. Melberg, 1995, Comparison of Alternatives for Sampling and Storage of VOCs in Soil. Proceedings of the Waste Testing and Quality Assurance Symposium, American Chemical Society, pp. 51-57.

U.S. EPA, 1990, Method 8021: Halogenated and Aromatic Volatiles by Gas Chromatography Using Electrolytic Conductivity and Photoionization Detectors in Series: Capillary Technique. Test Methods for Evaluating Solid Waste: Physical/Chemical Methods (SW-846), Vol. 1B, 3rd Ed. 
APPENDIX A

ASTM Draft Practice 
THIS DOCUMENT IS NOT AN ASTM STANDARD; IT IS UNDER CONSIDERATION WITHIN AN ASTM TECHNICAL COMMITTEE BUT HAS NOT RECEIVED ALL APPROVALS REQUIRED TO BECOME AN ASTM STANDARD. IT SHALL NOT BE REPRODUCED OR CIRCULATED OR QUOTED, IN WHOLE OR PART, OUTSIDE OF ASTM COMMITTEE ACTIVITIES EXCEPT WITH APPROVAL OF THE CHAIRMAN OF THE COMMITTEE HAVING JURISDICTION AND THE PRESIDENT OF THE SOCIETY.

\section{Standard Practice for Using a Coring Tube for Sampling and Storing Soil for Volatile Organic Analysis ${ }^{1}$}

\section{Scope}

1.1 This practice is intended for application to soils and sediments that may contain volatile waste constituents.

1.2 This practice provides a procedure for using a coring tube for sampling and storing soil for volatile organic analysis. It provides a simple means for holding soil samples for volatile organic analysis during shipment to the laboratory, and if the volatile contaminant levels in the soil are not known, the device can hold the sample so the proper sample preparation method, low-level or highlevel, can be determined by screening a replicate sample. Once this determination is made, the sample for analysis is transferred without disturbing its integrity into the appropriate container for analysis or preservation in methanol. Information on maximum storage times and temperatures to prevent loss of volatile compounds due to volatilization and/or biodegradation from the time of collection until analysis or transfer to methanol in the laboratory is also provided. This practice does not use methanol preservation in the field.

1.3 It is recommended that this standard be used in conjunction with Guide D 4687 and Guide D 4547.

1.4 This standard does not purport to address all of the safety concerns, if any, associated with its use. It is the responsibility of the user of this standard to establish appropriate safety and health practices and determine the applicability of regulatory limitations prior to use.

${ }^{1}$ This practice is under the jurisdiction of ASTM Committee D-34 on Waste Management and is the direct responsibility of Subcommittee D-34.01 on Sampling and Monitoring. 


\section{Referenced Documents}
2.1 ASTM Standards:
D 4547 Guide for Sampling Waste and Soils for Volatile Organics ${ }^{2}$
D 4687 Guide for General Planning of Waste Sampling ${ }^{2}$

\section{Summary of Practice}

3.1 This practice provides a procedure for using a coring tube for sampling and storing soil for volatile organic analysis. If volatile contaminant levels in the soil being sampled are not known, collection of at least two samples from each sampling location using the coring tube is recommended, (see Note 1). In this way, the proper sample preparation method for low-level or high-level volatile analysis, such as described in References $(1 \text { and } 2)^{3}$, can be determined by screening one sample for high or low concentrations of volatile organic compounds. If a low concentration is present, the second sample is extruded into the appropriate vial for low-level analysis; if a high concentration is present, the second sample is extruded into methanol for high-level analysis. In both cases, the sample is transferred from the storage chamber without disturbing sample integrity.

NOTE 1--For reporting sample results on a dry weight basis, an additional sample from each sampling location is required for determination of moisture content.

3.2 After the sample is collected in the coring tube, the tube is sealed with a slide-on cap and immediately becomes a vapor-tight chamber for storing the soil sample. Maximum storage times and temperatures to prevent loss of volatile compounds due to volatilization and/or biodegradation from the time of collection until analysis or transfer to methanol in the laboratory are provided. The practice does not use methanol preservation in the field.

\section{Significance and Use}

4.1 This practice is for use in collecting and storing soil samples for volatile organic analysis in a manner that prevents loss of contaminants due to volatilization and/or biodegradation.

4.2 In performing the practice, the integrity of the soil sample structure is maintained during sample collection, storage, and transfer in the laboratory for analysis.

\footnotetext{
${ }^{2}$ Annual Book of ASTM Standards, Vol 11.04.

${ }^{3}$ The numbers in parentheses refer to the list of references at end of this standard.
} 
4.3 During sample collection, storage, and transfer, there is very limited exposure of the sample to the atmosphere.

4.4 Laboratory subsampling is not required when performing this practice. The sample is expelled directly from the storage chamber into the appropriate container for analysis or preservation without disrupting the integrity of the sample.

4.5 The apparatus specified for use in this practice serves as both the sampling device and vapor-tight storage chamber. It has no threads for trapping particles and preventing a vapor-tight seal, and also has no septa through which volatile organic compounds can diffuse and contaminate the soil sample during shipment and storage.

4.6 This practice specifies the maximum length of time during which samples in the vapor-tight storage chamber can be stored on ice (temperature not to exceed $4^{\circ} \mathrm{C}$ ) before loss of volatile organic compounds may occur. It also specifies the maximum length of time during which samples in the vapor-tight storage chamber can be stored on dry ice (temperature not to exceed $-15^{\circ} \mathrm{C}$ ) before loss of volatile organic compounds may occur.

4.7 The practice does not use methanol preservation in the field. As a result, there are no problems associated with flammability hazards, shipping restrictions, or dilution of samples containing low volatile concentrations.

4.8 This practice cannot be used for sampling cemented material or material having fragments coarse enough to interfere with proper coring techniques.

\section{Apparatus}

5.1 Sampling/Storage Device--Any cylindrical coring tube that is volumetrically designed to collect a five-gram sample and is equipped with (1) a slide-on cap having a vapor-tight seal, such as provided by a Viton O-ring in the cap, and (2) a plunger for nondisruptive extrusion of the sample into an appropriate container for analysis, (see Fig. 1). A cap screwing onto the coring tube is not acceptable because soil particles can become lodged in the threads of the cap and prevent a vaportight seal. The device must be constructed of material that will not sorb or leach constituents of interest and must be cleaned in a manner consistent with the analyses to be performed. See Guide D 4687 for information on cleaning sampling equipment.

5.2 Minimum/Maximum Thermometer--Any thermometer that registers the minimum and maximum temperatures in ${ }^{\circ} \mathrm{C}$ reached during any given period of time and has a range that includes greater than $4^{\circ} \mathrm{C}$ and less than $-15^{\circ} \mathrm{C}$ in divisions of $1^{\circ} \mathrm{C}$.

\section{Procedure}

6.1 If volatile contaminant levels in the soil being sampled are not known, it is recommended that at least two samples be collected at each sampling location using the coring tube, (see Note 1). 
In this way, the proper sample preparation method for low-level or high-level volatile analysis, such as described in References ( 1 and 2$)^{3}$, can be determined by screening one sample for high or low concentrations of volatile organic compounds. If a low-concentration is present, the second sample is extruded into the appropriate vial for low-level analysis; if a high concentration is present, the second sample is extruded into methanol for high-level analysis. For quality assurance considerations related to field sampling, see Guide D 4687.

6.2 Sample Collection--Push the coring tube into the soil to capture a tight volume of soil. If there is uncertainty about whether the sample chamber is full, push the tube into the soil a second time. Sample collection should be performed as quickly as possible. See Guide D 4547 for guidance on sample collection. Additional information on technique, precautions, etc.?

6.2.1 Quickly wipe the external surface of the coring tube with a clean tissue or cloth and push the coring tube cap onto the sampling device to seal it. Additional information on technique, precautions, etc.?

6.3 Sample Storage--The capped sampling device immediately becomes a sealed sample storage chamber until the sample is analyzed or preserved in methanol. Samples stored at temperatures that do not exceed $4^{\circ} \mathrm{C}$ can be held in the sealed storage chamber for no longer than 48 hours before being transferred for the appropriate high or low-level volatile analysis. Samples stored at temperatures that do not exceed $-15^{\circ} \mathrm{C}$ can be held in the sealed storage chamber for no longer than $\mathrm{X}$ days before being transferred for the appropriate high or low-level volatile analysis. For information on how these holding times and temperatures were determined, see Appendix $\mathrm{X}^{4}$.

6.3.1 Storage of samples at temperatures not to exceed $4^{\circ} \mathrm{C}$ can be achieved by placing the storage device in a cooler with ice or in a refrigerated compartment regulated at $4^{\circ} \mathrm{C}$ or less. Storage of soil samples at temperatures not to exceed $-15^{\circ} \mathrm{C}$ can be achieved by placing the storage device in a cooler with dry ice or in a refrigerated compartment regulated at $-15^{\circ} \mathrm{C}$ or less. In both cases, a minimum/maximum thermometer must be placed with the samples in the cooler or refrigerated compartment to verify that the temperature requirements were maintained. Transportation of dry ice from the field to the laboratory must comply with current Department of Transportation (DOT) regulations ${ }^{5}$.

${ }^{4} \mathrm{~A}$ copy of the research report on the study described in Appendix X1 is available from ASTM headquarters. Request RR: D34-XXXX.

${ }^{5}$ These are available from the Superintendent of Documents, U.S. Government Printing Office, Washington, DC 20402. The shipper used to transport the samples to the laboratory can also provide information on shipping regulations and requirements. 
6.4 Arrangements with the laboratory for sample handling, logging in, required storage conditions, and analysis must be made. At the laboratory, the soil is quickly transferred into the appropriate container for volatile analysis without disturbing the integrity of the sample by removing the cap from the storage chamber and using the plunger to expel the soil into the receiving container.

6.5 The sampling device must be disassembled and washed between each use. See Guide D 4687 for information on cleaning sampling equipment.

\section{Report}

7.1 The sampling report shall include the following:

7.1.1 Name and location of the site,

7.1.2 Date and time of sampling,

7.1.3 Sampling location,

7.1.4 Sample number,

7.1.5 Description and disposition of the sample,

7.1.6 Name of sampling personnel,

7.1.7 Sampling conditions and analytical requirements,

7.1.8 Packing conditions for shipment of the sample(s) to the laboratory for analysis, shipper used, and date of shipment.

\section{Precision and Bias}

8.1 Precision ${ }^{6}$--Data on the precision of this sampling/storage procedure is currently being generated.

8.2 Bias--No information can be given on the bias of the sampling/storage procedure described in this practice because there is no standard reference material for sampling soil for volatile organic compounds in the field. However, information on the bias introduced by storage of a soil sample

${ }^{6}$ A copy of the research report used to develop the precision statement is available from ASTM Headquarters. Request RR: D34-XXXX. 
in the sampling/storage device used in this practice is provided by the data generated in the study described in Appendix X1 and the research report RR: D34-XXXX'. These data show that for the storage conditions specified in section 6.3 of this practice (no longer than 48 hours at temperatures not exceeding $4^{\circ} \mathrm{C}$ or no longer than $\mathrm{X}$ days at temperatures not exceeding $-15^{\circ} \mathrm{C}$ ), there is no significant difference between the concentrations of benzene, toluene, ethylbenzene, M/P-xylene, $\mathrm{O}-$ xylene, 1,3,5-trimethylbenzene, 1,2,4-trimethylbenzene, 1,2-dichloroethane, trichloroethylene, and tetrachloroethylene in samples of contaminated sand ( $\sim 85 \%$ sand $/ \sim 15 \%$ clay), loamy clay low in bacterial population, and loamy clay high in bacterial population analyzed immediately after sampling and samples of the same materials analyzed after being stored in the device under the specified conditions. This is shown by the data presented in Tables 1 and 2 (Tables 1 and 2 will be provided when data are available.). These data were generated by applying a two-tailed $t$ test for significance at the $5 \%$ level to the concentration data generated from immediate analysis (time-zero concentrations) of samples of the contaminated soils and the concentration data generated by analysis of samples of the contaminated soils stored under the specified conditions. As shown in Tables 1 and 2 , the differences between the time-zero concentrations and the concentrations determined after storage in the device are not statistically significant at the 5\% level.

\section{Keywords}

9.1 Soil sampling; storage of soil samples; volatile organic compounds; coring tube; sample storage times; sample storage temperatures 


\section{REFERENCES}

1. U.S. EPA, 1990, Method 8240A: Volatile Organics by Gas Chromatography/Mass Spectrometry (GC/MS): Packed Column Technique. Test Methods for Evaluating Solid Waste: Physical/ Chemical Methods (SW-846), Vol. 1B, 3rd Ed.

2. U.S. EPA, 1990, Method 8260: Volatile Organic Compounds by Gas Chromatography/Mass Spectrometry (GC/MS): Capillary Column Technique. Test Methods for Evaluating Solid Waste: Physical/Chemical Methods (SW-846), Vol. 1B, 3rd Ed. 


\section{APPENDIX}

\section{(Nonmandatory Information)}

\section{X1. Determination of Maximum Storage Times and Temperatures}

X1.1 When soil is sampled for analysis of volatile organic compounds, the samples must be collected and stored in ways to prevent loss of those compounds. Loss of volatile organic compounds can occur through volatilization and/or biodegradation.

$\mathrm{X} 1.2$ In developing this practice, research to determine the maximum length of time during which samples in the vapor-tight storage chamber can be stored on ice (temperature not to exceed $4^{\circ} \mathrm{C}$ ) and on dry ice (temperature not to exceed $-15^{\circ} \mathrm{C}$ ) before loss of volatile organic compounds may occur was conducted.

X1.2.1 Three soils were used in this research. These were a sand ( $\sim 85 \%$ sand $/ 15 \%$ clay), a loamy clay low in bacterial population, and a loamy clay high in bacterial population. Ten percent deionized water by weight was added to the soils to simulate natural hydration. The soils were spiked with gasoline plus a mixture of halogenated solvents (1,2-dichloroethane, trichloroethylene, and tetrachloroethylene). Spiking was performed so that sample preservation in methanol would be required for analysis (high-level sample preparation method). The soils were homogenized with respect to both soil composition and contaminant levels by placing the soil, along with the contaminant spike, in a 20-gallon drum having ten mixing blades welded to its interior surface. The drum was sealed and placed inside an insulated, refrigerated box having a temperature ranging from 7 to $12^{\circ} \mathrm{C}$. Mixing was performed by horizontally rotating the drum at 5.5 rotations per minute for 16 to 18 hours $(3,4)$.

X1.2.2 After each soil was mixed for 16-18 hours, ten five-gram samples were collected and immediately extruded into methanol for preservation and analysis. These samples were analyzed using EPA Method 8021 to give time-zero concentrations of benzene, toluene, ethylbenzene, M/Pxylene, O-xylene, 1,3,5-trimethylbenzene, 1,2,4-trimethylbenzene, 1,2-dichloroethane, trichloroethylene, and tetrachloroethylene in the soil and to provide homogeneity information on the spiked soil (5). Table X1.1 shows the mean concentrations in the time-zero samples, as well as the standard deviations, percent relative standard deviations, and $95 \%$ confidence intervals for the replicate values determined for each compound in each soil type (Table X1.1 will be provided when data are available.). Further discussion of homogeneity.

X1.2.3 Also, after each soil was mixed for 16-18 hours, additional samples were collected using a stainless steel sampling/storage device fitting the apparatus description given in section 5.1 of this practice. These samples were stored at various temperatures and for various lengths of time prior to volatile organic analysis for the compounds listed in section X1.2.2. The mean concentrations of those compounds in the samples stored at various temperatures and for various lengths of time prior to volatile organic analysis are listed in Table X1.2 (Table X1.2 will be provided when data are available.). 
X1.2.4 The bias introduced by storage of the samples in the sampling/storage device was statistically evaluated as described in ASTM D 2777, Standard Practice for Determination of Precision and Bias of Applicable Methods of Committee D-19 on Water (6). The bias was evaluated for significance at the five percent level. Bias information for the storage conditions of 48 hours at $4^{\circ} \mathrm{C}$ and $\mathrm{X}$ days at $-15^{\circ} \mathrm{C}$ is presented in Tables 1 and 2 of this standard (Tables 1 and 2 will be provided when data are available.). These data show that storage of the soil samples in the sampling/storage device at $4^{\circ} \mathrm{C}$ for 48 hours and at $-15^{\circ} \mathrm{C}$ for $\mathrm{X}$ days does not result in significant loss of the volatile organic compounds of interest at a five percent significance level. As a result, these storage times and corresponding temperatures were selected for specification in this standard. 


\section{APPENDIX REFERENCES}

3. King, P., 1993, Evaluation of Sample Holding Times and Preservation Methods for Gasoline in Fine-Grained Soils. Proceedings from the National Symposium on Measuring and Interpreting VOCs in Soils: State-of-the-Art and Research Needs, U.S. EPA, Las Vegas, NV.

4. Turiff, D., and C. Klopp, Date, Studies of Sampling, Storage and Analysis of Soils Contaminated with Gasoline and Diesel. Internal report, En Chem, Inc., Green Bay, WI.

5. U.S. EPA, 1990, Method 8021: Halogenated and Aromatic Volatiles by Gas Chromatography Using Electrolytic Conductivity and Photoionization Detectors in Series: Capillary Technique. Test Methods for Evaluating Solid Waste: Physical/Chemical Methods (SW-846), Vol. 1B, 3rd Ed.

6. American Society for Testing and Materials, 1991, ASTM Practice D-2777-86, Standard Practice for Determination of Precision and Bias of Applicable Methods of Committee D-19 on Water. Annual Book of ASTM Standards, 11.01: 31-44. 


\section{APPENDIX B}

Testing Plan for Determining Maximum Storage Times and Temperatures 


\title{
Testing Required for Development of the Draft ASTM Practice for Using a Coring Tube for Sampling and Storing Soil for Volatile Organic Analysis
}

\author{
Susan Sorini \\ WRI \\ February 4, 1997
}

I. Testing to verify 48 hours/temperature not to exceed $4^{\circ} \mathrm{C}$ storage conditions before methanol preservation (to be performed first using the 5-gram stainless steel device and then using the 5-gram RTP device)/Testing to evaluate freezing as a recommended option if samples cannot be preserved within 48 hours (to be performed first using the 5gram stainless steel device and then using the 5-gram RTP device)
A. Soil types: $\quad \sim 85 \%$ sand with $\sim 15 \%$ clay-worst case for volatilization Loamy clay-low bacterial population
Loamy clay-high bacterial population

With $10 \%$ deionized water by weight added to simulate natural hydration of most soils

B. Compounds: Gasoline plus mixture of halogenated solvents (1,2dichloroethane, trichloroethylene, tetrachloroethylene)

C. Preparation of spiked soils:

Spiking performed so that sample preservation in methanol will be required for analysis ("high concentration")

\section{Mixing for 16-18 hours}

D. Collection of samples:

Take 10 samples for immediate methanol preservation--These will serve as the time zero samples and will also be used to provide information on the spiked soil. The $95 \%$ confidence intervals for the concentrations of the analytes of interest in the soil will be calculated using the data from analysis of the 10 samples.

Take 5 48-hour/temperature not to exceed $4^{\circ} \mathrm{C}$ storage samples--Store on ice and monitor temperature to make sure it is at $4^{\circ} \mathrm{C}$ 
D. Collection of samples cont'd: Take 5 samples--Samples on ice for 48 hours with temperature monitored to make sure it is at $4^{\circ} \mathrm{C}$ followed by 5 days of refrigeration at $4^{\circ} \mathrm{C}$

Take 5 samples--Samples on ice for 48 hours with temperature monitored to make sure it is at $4^{\circ} \mathrm{C}$ followed by 12 days of refrigeration at $4^{\circ} \mathrm{C}$

Take 5 samples--Samples on ice for 48 hours with temperature monitored to make sure it is at $4^{\circ} \mathrm{C}$ followed by 19 days of refrigeration at $4^{\circ} \mathrm{C}$

Take 5 samples for 48 -hour storage at $-15^{\circ} \mathrm{C}$

Take 5 samples each for 7,14, and 21-day storage at $-15^{\circ} \mathrm{C}$

E. Storage of samples

Need to record storage temperatures and make sure that they are as close as possible to the maximum temperature specified $\left(4^{\circ} \mathrm{C} /-15^{\circ} \mathrm{C}\right)$

F. Analyze samples at appropriate times and report results as the percent of the time zero concentration present in the sample--Concentration data will also be sent to WRI for evaluation. In this way, En Chem determinations can be verified.

G. For frozen samples, pay special attention to any effects of freezing on the viton $o$-rings and the RTP material

II. Specifications for storage times and temperatures will be included in the practice. Data generated by the testing described above will be included in the appendix to the practice. In ASTM standards, an appendix can be included to provide supplementary information to aid the user in understanding and utilizing the standard.

III. Final verification--After data are generated on storage times and temperatures, samples can be prepared at En Chem in the EnCore ${ }^{\mathrm{TM}}$ sampler and sent to WRI under the storage and handling conditions that are to be specified in the practice. The samples will then be analyzed by WRI. This will provide verification of the storage and handling conditions that will be specified in the practice with actual shipping from one location to another. Replicate samples 
will also be stored under the specified conditions and analyzed at En Chem as a check to determine if any volatile losses are due to shipping from one location to another.

A. Test each temperature/storage time condition

B. Same soils/compounds tested in I

C. 5 replicates

D. Report results as the percent of the time zero concentration present in the sample

E. Needs to be performed for both stainless steel and RTP devices

Summary of Testing Outlined in I.

\begin{tabular}{|c|c|c|c|c|}
\hline & No storage & $\begin{array}{l}\text { Not to exceed } \\
4^{\circ} \mathrm{C} \text { (on ice) }\end{array}$ & $\begin{array}{l}\text { Not to exceed } \\
4^{\circ} \mathrm{C} \text { (on ice then } \\
\text { refrigerated) }\end{array}$ & $\begin{array}{l}\text { Frozen (not to } \\
\left.\text { exceed }-15^{\circ} \mathrm{C}\right)\end{array}$ \\
\hline Time 0 & 10 & & & 5 \\
\hline 48 hours & & 5 & & 5 \\
\hline 7 days & & & 5 & 5 \\
\hline 14 days & & & 5 & 5 \\
\hline 21 days & & & 5 & \\
\hline
\end{tabular}

The testing described above will require 40 sampling devices.

With the 21-day storage for each of the test materials, this testing will take approximately 9 weeks for each material of construction. 